\section{Response to Pross}

SIR

We of the German Association on the Political Abuse of Psychiatry agree with the statements made by Christian Pross in his paper, 'Breaking through the postwar coverup of Nazi doctors in Germany' (1) to a large extent. The attitude of covering up was experienced by me as late as 1989 , a few weeks after the Deutsche Ärztetag, the representative body of German doctors, had managed openly to acknowledge the profession's guilt in some of the most atrocious Nazi crimes.

At the World Congress of Psychiatry in Athens I brought up the subject of psychiatric abuse in the USSR and the, at times, rather reluctant resistance against it. When I mentioned in this context that 'there has only recently been wider and deeper discussion amongst doctors about the terrors of the Nazi era in my country', I was publicly accused of not telling the truth by the then acting president of the German Psychiatric Association who-in spite of the fact that his own life had been affected by Nazi persecution - claimed that much had been done by German doctors to debate this issue.

The truth seems to be somewhere in the middle between this assertion and the opinion of Pross who denies any sense of remorse within the medical profession in postwar Germany and claims all activity to redress these attitudes for his own faction.

As a student in the early sixties I read A Mitscherlich's and F Mielke's book Medizin ohne Menschlichkeit (Medicine Without Humanity) which at that time was easily available as a paperback. Psychiatrie der Verfolgten (Psychiatry of the Persecuted) by $\mathrm{W}$ von Baeyer, $\mathrm{H}$ Häfner and K P Kisker, published in 1964, also appeared to me to be a serious attempt to 'digest and overcome'. Believing that the most urgent tasks had been accomplished, I and other colleagues, at the beginning of the seventies, turned against current criminal actions within the medical profession and against a current 'complicity of silence and coverup' which, in effect, was condoning those criminal actions.

Faced with numerous reports of abuses of psychiatry in the Soviet Union at that time we became engaged in fighting against such abuses and on behalf of their victims accomplished for them quite a few things but never managed in the following 20 years to have the Deutscher Ärztetag name the Soviet Union as the centre of such abuses and stop the perpetrators by singling them out.

Of course, the Ärztetag has always been in 'good company' since large parts of the intellectual elite of this country ignored the crimes of the Soviet system at that time. Pross's 'national conference of doctors and health workers', the 'Gesundheitstag', and most of the leftist doctors, did so as well. To be sure, many more aspects of Nazi terror were revealed by these groups in the eighties. And they showed concern also about current events, such as victims of torture - particularly when they came from Chile, Turkey or South Africa.

Those who interceded for victims of psychiatric abuse in the Soviet Union, however, were silenced or insulted by these groups; amongst those who were so insulted was Professor Walter von Baeyer, the former Vice-President of the World Psychiatric Association (1966-1971). 'Anti-Communism' was still the mildest form of insinuation. The 'complicity of silence and coverup in the German medical profession' was manifested in this respect in various forms by various factions.

Since Pross highlighted (2) Professor Toellner's lecture at the Deutsche Ärztetag in 1989 as a turning point towards a sincere confrontation with the Nazi past by German doctors, Professor
Toellner's conclusions should not be omitted: 'Where the doctor allows himself to be used as an instrument', he concluded, 'where the doctor allows himself himself to be deprived of his indivisible responsibility for his professional conduct and decisions, or delegates them, where the doctor does not protect and preserve life but extradites and kills, where the doctor usurps the decision about the value of a human life ..., where the medical profession does not secure and protect the ethical standards of medicaf conduct, there the doctors jeopardise their profession, their mission and themselves. The history of doctors in the "Third Reich" teaches us so ...'

\section{References}

(1) Pross C. Breaking through the postwar coverup of Nazi doctors in Germany. Fournal of medical ethics [supplement] 1991; 4: 13-16.

(2) See reference (1): 15.

DR FRIEDRICH WEINBERGER, German Association on the Political Abuse of Psychiatry, Walter-von-BaeyerGesellschaft eV, President, Maximilianstr 6, W8130 Starmberg, Germany.

\section{HIV-positive surgeon}

SIR

The publicity surrounding yet another case of a surgeon who may be HIVpositive, has highlighted public anxiety and perhaps the shortcomings of present guidelines pertaining to the HIV status of practising doctors.

There are two interrelated aspects to address. Firstly, those individuals who are not HIV-positive, but are within a higher risk category for contracting infection. Secondly, those who have already sero-converted. 
With respect to the former group, there are few intravenous drug abusers or haemophiliacs within the medical profession. Therefore by implication, in a country where heterosexual (vaginal) transmission of the virus, though having increased by 65 per cent over the past year, remains statistically low, those in higher-risk categories will tend to be homosexual and bisexual men. It is not for society or professional bodies to comment on nor indeed legislate on the sexual proclivities or practices of doctors.

However, with regard to surgeons, who constitute a special subgroup, there is a definite, albeit very minimal risk to patients from an HIV-positive operator (1). Therefore it is difficult to condone certain life-styles which render some doctors (ie surgeons) at higher risk of infection. 'Safer sex' is no guarantee against contracting infection, which may go unsuspected. The sexual history of gay partners in particular is often enigmatic, and 20 per cent of gay men attending London GU clinics are HIVpositive. Thus at the very least such individuals should be obliged to undergo regular testing. At most, one could advocate celibacy (or monogamy). That would perhaps be unrealistic and hypocritical - though arguably not an unreasonable price to pay for the social and financial rewards of the profession.

For those who are already HIVpositive, I believe there is a moral obligation to declare such a fact, and to face the consequences as dictated by available data and society's mores. At present such data do indeed suggest the risk of infecting a patient to be extremely low (2) unless a surgeon were to sustain a needle-stick injury or cut and then deliberately squeeze blood into a patient's open wound (though unforeseeable accidents can occur).

However, HIV infection is potentially fatal and a patient should have the right to know if a surgeon is HIV-positive. It is naive to believe that patients are invariably willing to submit themselves to major elective surgery to be performed by an HIV-positive surgeon when equally competent seronegative operators are available. Whether any patient's fears are unjustified statistically is insufficient; patients are going to react emotionally and not rationally to this issue.

I agree with the HIV committee of the Royal College of Surgeons that any kind of 'witchhunt' would lead to discrimination and to doctors at higher risk failing to undergo testing voluntarily. It behoves doctors to consider their responsibility to patients and society. At present it is recommended that HIV-positive surgeons refrain from 'major invasive procedures' (3). Any kind of selective surgical practice would be difficult to implement without undermining the status of a consultant. In reality, a complete cessation of practice may be called for.

Recent American legislation has no doubt been prompted by fears of litigation. However, this is principally an ethical and not a legal issue. Hopefully those individuals concerned will eventually resolve themselves to their professional (and personal) fate.

\section{References}

(1) HIV infection: hazards of transmission to patients and health care workers during invasive procedures. The Royal College of Pathologists, 1992.

(2) Statement to fellows on AIDS and $H I V$ infection. The Royal College of Surgeons of England. 1992, March.

(3) AIDS: HIV-infected health care workers. Report of the recommendations of the Expert Advisory Group on AIDS. DHSS. London: HMSO, 1988.

J R BENSON, MA, FRCS, Clinical Research Fellow, Institute of Cancer Research and The Royal Marsden Hospital. 